south, it will probably be found that few towns and villages have escaped some injury. The isoseismal line of intensity 8 , or the curve which bounds the area of slight damage to buildings, seems to be roughly elliptical in form, about twenty-eight miles from east to west and eighteen to twenty miles from north to south, or a little more than Ioo square miles in area.

Nearly all the strongest British earthquakes belong to the class which have been called "twin" earthquakes. They originate within two foci, which are nearly or quite detached, with their centres, as a rule, about eight or ten miles apart. But the chief peculiarity about them is that the two impulses which cause them take place almost simultaneously, or, if not quite so, that the second impulse occurs before the vibrations from the first focus have time to reach the other, the two impulses being thus due to a single generative effort.

From the descriptions which have been given there can, I think, be no doubt that the recent shock was a typical twin earthquake. Many hundreds of observations will be required to determine the positions of the twin foci, and to ascertain which focus was first in action. But, so far as the evidence already collected allows us to judge, the foci appear to have been situated along a nearly east and west line, and are probably coincident with an east and west fault, passing close to Llanelly, Swansea, and Neath. It would be useless at present to attempt a more exact definition of the originating fault, but it is clearly connected with the great Armorican system of crust-movements, which attain their maximum in Brittany and midDevon, and, as they enter South Wales, begin to die away. In this district, as Mr. Aubrey Strahan remarked in his address at the Cambridge meeting of the British Association, the chief disturbances are of post-Carboniferous age. That they are still occasionally continued, though on a much smaller scale, the recent shock bears ample testimony.

It is evident from the above account that the earthquake presents several features of considerable interest to geologists. The district is also one that affords unusual opportunities for the study of the nature and effects of the shock in deep mines, and it is to be hoped that our somewhat scanty knowledge will be advanced in this respect.

I take this opportunity of stating how greatly my investigation of the earthquake would be assisted by the contribution of records from different places, and especially from the workings in the mining districts. The points on which I wish to obtain information will be found in many local newspapers, but I shall be glad to send forms on which descriptions may be conveniently entered if application is made to me at I6 Manor Road, Edgbaston, Birmingham.

\section{Charles Davison.}

PROFS. N. S. SHALER AND I. C. RUSSELL.

GEOLOGICAL science, and America in particular, has suffered a severe loss in the deaths of two university professors, N. S. Shaler, of Harvard, and I. C. Russell, of Michigan.

Prof. Nathaniel Southgate Shaler, who was born in Newport, Kentucky, on February 20, 184I, graduated at Harvard University, and served two years as an artillery officer in the Union Army during the Civil War. Subsequently he pursued the study of natural science, to which he had boen attracted at the Lawrence Scientific School in Cambridge, took the degree of Sc.D. in $186_{5}$, and became in 1868 instructor in zoology and geology in that school, and also professor of palæontology in Harvard University While retaining this professorship, he was in 1873 appointed director of the second Kentucky Geological Survey, a post he held until $\mathrm{I} 880$; and in 1887 he became professor of geology in Harvard University, and occupied the chail until his death this year at the age of sixty-five. When little more than twenty years of age he discussed the age of the rocks in Anticosti, in a paper read before the Boston Society of Natural History, and in 1865 and following years he brought before the same society his views on the elevation of continental masses, arguing that seabottoms on which sedimentation was taking place were areas of depression, and that prominent lands undergoing denudation were areas of uplift. He discussed the formation of mountain chains (I866), and maintained that while the continental folds were corrugations of the mass of the earth's crust, the mountain chains were folds only of the outer portion of the crust caused by contraction of its underlying part, and that the formation of mountain chains would be promoted by the subsidence of the ocean's floors, fractures and dislocations being thereby produced along their borders (see G. P. Merrill's "Contributions to the History of American Geology," 1906). In a subsequent paper (1875) Shaler suggested that the transfer of weight to the land by the accumulation of an ice-sheet would influence terrestrial movements. He also discussed the possibility of the Japan current flowing at the close of the Glacial period over what is now land about Bering's Strait, and thus modifying the climatic conditions. He issued memoirs and reports on the geology of Kentucky ( $876,8 \mathrm{c}$.), and in later years dealt with a great variety of subjects, scientific and practical, including the classification of lavas, the fossil brachiopods of the Ohio valley, soils, the geological history of harbours, peatdeposits, road-stones, the features of the earth and moon, \&c. He was author of important reports on the geology of Cape Cod district (1898); (with J. B. Woodworth) geology of the Richmond Basin, Virginia (1899); and (with A. F. Foerste) geology of the Narragansett Basin (1899). He wrote also "Outlines of the Earth's History" (I898); "Sea and Land: Features of Coasts and Oceans, with Special Reference to the Life of Man" (1895); "Study of Life and Death" (1900), and other works of a more or less popular character.

Prof. Israel Cook Russell, whose death occurred at the age of fifty-three, was born at Garrattsville, in New York State, on December $10,185^{2}$. He graduated at the University of New York in 1872 , and after further study at the School of Mines, Columbia, was appointed a member of the U.S. expedition to New Zealand $(1874-5)$ to observe the transit of Venus. His attention, however, was given mainly to the study of physical geology. On his return from New Zealand he became assistant professor of geology at the Columbia School of Mines, and in 1878 was appointed assistant geologist on the U.S. geographical and geological survey west of the one hundredth meridian. From 1880 to 1892 he served as geologist on the U.S. Geological Survey, and in 1892 he became professor of geologv in the University of Michigan. His earlier papers (1878) dealt with the physical history of the Trias in New Jersey, and with the intrusive nature of the eruptive rocks, in which he recorded the presence of a solid hydrocarbon. One of his more important works was a sketch of the geological history of the former Lake Lahontan, which in Quaternarv times occupied an area of nearly 8,500 square miles in N.W. Nevada (1883); he wrote also on the glaciers of Mount Rainier (1898), and on the geology of the Cascade Mountains (I90o). Of later

NO. I 9 I4, VOL. 74$]$ 
papers mention may be made of his observations on the Sniake River plains, on the water-bearing strata of Idaho and Oregon, and on the volcanic eruptions of Martinique and St. Vincent. He was author of separate and more popular works on the lakes, glaciers, volcanoes, and rivers of North America.

\section{NOTES.}

ONLY a few names familiar in the scientific world occur in the long list of honours announced on Friday last in celebration of the King's birthday. Lieut.-Colonel D. Prain, F.R.S., director of the Royal Gardens, Kew, and late director of the Botanical Survey of India, has been appointed a Companion of the Order of the Indian Empire. Sir Christopher Nixon, ex-president of the Royal College of Physicians, Ireland, and the author of various papers on diseases of the heart and nervous system, has received the honour of a baronetcy. Among the thirty new knights are Mr. T. Digby Pigott, Emeritus Prof. A. R. Simpson, and Dr. A. E. Wright. Sir John Brunner, a member of the great firm of alkali manufacturers, Brunner, Mond and Co., has been made a privy councillor.

BRITISH merchants and manufacturers anticipated a great development of our trade in the Far East at the close of the Russo-Japanese War last year; but it appears from a special inquiry instituted by the Daily Mail that their expectations have not been realised. There has been a noteworthy expansion of trade since peace was concluded last August, but the Japanese have taken care that the chief advantages of it shall be to themselves. They have not only secured the Far Eastern market, but, according to our contemporary, the Japanese Government is laying plans for becoming our rivals as an exporter of goods to India. "The fault," we read, " is chiefly our own. Our Government neither knows what is going on nor takes any measures to protect our interests. It is quite natural that Japan should seek to take the current when it serves, but we, too, ought to have our share of the flood that leads on to fortune, and if the Far Eastern department of the Foreign Office will kindly wake up we may secure it yet." It is evident that the Japanese, with their scientific knowledge and methods, will be as strong in peace as they have proved themselves in war. This is an age when science and system are essential to progress, and the ration that realises it is best equipped for survival in the struggle for commercial supremacy. Only by insisting that the scientific spirit which permeates Japanese education and policy shall be possessed by our own statesmen can our commercial position be made secure against attack or progress be assured, either now or in the future.

In the House of Lords last week, Lord Onslow asked whether His Majesty's Government proposed to continue to take part, after next year, in the international investigations of North Sea fisheries, and made some observations by way of criticism of the methods of investigation which the International Council has adopted. The gravamen of Lord Onslow's objection to the scheme appears to be that, whilst in his opinion the most promising method of attacking fishery problems is by the collection of statistical information from the commercial fishing vessels and at the ports of landing, in the international scheme the carrying out of accurate investigations at sea by men of scientific education and training on board specially equipped research steamers is regarded as essential to an adequate study of the very complicated problems which present themselves to those responsible for the regulation No. I 9 I 4, voL. 74] of the fisheries. The value of such collections of statistical data as Lord Onslow suggests, as an adjunct to work carried out by special research steamers, cannot be doubted, and, judging from the reports already published, appears to be fully recognised by the International Council. But no one with experience of the fundamental necessity of accurate observation and scientific method in dealing with practical problems of this character will, we imagine, for a moment be able to agree with the suggestion that such collections of miscellaneous information, the trustworthiness of which must necessarily vary greatly in different cases, can adequately supersede the observations and experiments of skilled investigators. The results already foreshadowed by the International Council seem to be of a promising character, and Lord Carrington, who replied for the Government, was well advised in postponing the consideration of the question of the continued participation of this country in the investigations until after the full reports have been received.

A MEETING was held on June $2 \%$ in support of the National Association for the Establishment of Sanatoria for Workers suffering from Tuberculosis. The secretary announced that the association is receiving the active cooperation of friendly societies. At the present time twenty-eight beds have been bespoken for the General Post Office, fifteen for the Hospital Saturday Fund, and five for the Hearts of Oak Benefit Society. Donations have been received from representatives of the participating classes, and this willingness of the ordinary public to assist men of science in their endeavours to eliminate a dreadful disease will greatly lighten their task. Mr. Chamberlain, in a speech supporting the scheme, pointed out that science has already done a good deal, and, without being too optimistic, it is likely that, from further discoveries and continued exertions of distinguished men engaged in medical research, perhaps in the near future the discovery of some definite specific remedy for the disease will be made. Cholera, diphtheria, and other diseases no longer have their terrors, and consumption may cease to be what it is at the present time. Mr. Chamberlain went on to say that he wished he could make his voice reach some of those who have, not merely too much wealth, but wealth beyond the dreams of avarice, which the possessors themselves recognise they cannot make any possible use of. He urged upon the men of great wealth that there is no possible thing they can do which will bring greater benefit to humanity at large, and give them greater satisfaction, than to endow further great schemes for medical research. While sympathising with the desire to see our millionaires emulating the example of American men of wealth in their support of scientific research, our statesmen should not lose sight of the fact that it is as much their duty to see to the protection of the people from disease as from foreign foes. The endowment of scientific and medical research is as necessary a form of national defence as a battleship, and to postpone the organisation of a State-aided campaign against a scourge like consumption until the generosity of millionaires has been developed is unstatesmanlike and a dereliction of duty on the part of Governments.

THE death of Señor Manuel Garcia in London on Sunday has deprived the worlds of science and music of a man whose work will be remembered so long as the human voice is used and studied. While the throat is capable of emitting musical sounds, and is liable to disease, the laryngoscope invented by Manuel Garcia will hold its unique 